\title{
The Kariba case - the watering down of the binding offer in South African business rescue proceedings
}

\author{
Eric Levenstein \\ BCom HDip Company Law, HDip Tax, Diploma in Insolvency Law, LLD, Attorney of \\ the High Court of South Africa \\ Director and Head of the Insolvency, Business Rescue \& Restructuring Department \\ at Werksmans Attorney
}

\section{OPSOMMING}

\section{Die Kariba saak - die afwatering van die bindende aanbod in Suid-} Afrikaanse ondernemingsredding

Hoofstuk 6 van die Maatskappywet 71 van 2008 ('die Maatskappywet 2008') het die konsep van ondernemingsredding ingevoer vir maatskappye wat onder finansiële druk verkeer. Die proses behels die rehabilitasie van sulke maatskappye deurdat dit die geleentheid skep om 'n ondernemingsreddingsplan voor te lê, gefasiliteer deur 'n ondernemingsreddingspraktisyn. So 'n plan stel 'n basis voor op grond waarvan die maatskappy kan voortgaan om handel te dryf as 'n solvente entiteit, of, in die alternatief, waarvolgens dit 'n beter dividend aan skuldeisers sal voorsien as wat hulle sou ontvang tydens likwidasie. Alle skuldeisers word gebind deur die plan en skuldeisers (aandeelhouers) wat teen die plan stem word potensieel daartoe gedwing om hulle stembelang te verkoop aan partye wat ten gunste van so 'n plan stem. Die konsep van die 'bindende aanbod' wat deur 'n skuldeiser (aandeelhouer) gemaak word aan die teenstemmende party is nuut in die Suid-Afrikaanse reg. Vanaf ' $n$ direkte interpretasie van die artikel, blyk dit dat die teenstemmende party word verplig om sy stembelang te verkoop aan die aanbieder teen die likwidasiewaarde van die betrokke stembelang (dikwels 'n verwaarloosbare bedrag). In hierdie artikel word artikel 153(1)(b)(ii) van die Maatskappywet 2008 ondersoek, asook die ontwikkeling van regspraak oor die onderwerp. Dit behandel ook die toekomstige vooruitsigte van die betrokke bepaling om voortaan skuldeisers (aandeelhouers) toe te laat om die ondernemingsreddingsplan af te forseer ('cramdown') op teenstemmende partye. Die artikel bespreek artikel 153(1)(b)(ii) van die Maatskappye Wet 71 van 2008, die ontwikkeling van die regspraak, en dit lyk of die artikel krediteure (aandeelhouers) kan toelaat om stemregte uit koop om te verseker dat die reddings plan aanvaar word, ondanks teenkanting van afwykende partye. In die besonder, sluit hierdie artikel 'n analise van African Banking Corporation van Botswana Bpk $v$ Kariba Furniture Manufacturers (Edms) Bpk en ander 2013 (228/2014) [2015] ZASCA 69 (20 Mei 2015) ('Kariba (SCA)'). Die uitspraak van die Hooggeregshof van Appèl (SCA) in die geval van Kariba (SCA) het die konsep van die bindende aanbod 'op sy kop' gedraai en as 'n gevolg was die bindende aanbod beginsel 'afgewater'. Die uitspraak van Kariba (SCA) het 'n groot invloed op die wyse waarop skuldeisers en aandeelhouers die meganisme in artikel 153(1)(b)(ii) beskou en het derhalwe onbruik geword. Dit word voorgelê hierin dat totdat die wetgewer artikel 153(1)(b)(ii) wysig, of totdat

How to cite: Levenstein 'The Kariba case - the watering down of the binding offer in South African business rescue proceedings' 2017 De Jure 241-262
http://dx.doi.org/10.17159/2225-7160/2017/v50n2a3 
daar 'n ander merkwaardige beslissing gemaak word deur die SCA (miskien op verskillende feite), die posisie onveranderd sal bly.

\section{Introduction}

Many jurisdictions require a specific provision in restructuring legislation to force dissenting creditors to accept the restructuring proposal. The mechanisms vary, but generally there is a requirement that allows one or more classes of creditors to ensure that the plan becomes binding on other classes (including in certain cases, on secured and priority creditors) that do not wish to support the plan. ${ }^{1}$ After all, if the aim of a restructuring mechanism is to allow for a rehabilitation of the company, its business and its affairs, it does not make sense that a small group of dissenting creditors should be allowed to dictate to the majority (larger) group of creditors who favour the implementation of the plan, albeit for their own peculiar interests. Westbrook et al. describe this procedure as one which is necessary to prevent obstruction of a feasible plan. ${ }^{2}$

Notwithstanding the ability to compel dissenting creditors to accept the plan, legislation should also protect the interests of these creditors who are 'forced to accept the plan', sometimes against their will. ${ }^{3}$ Protective mechanisms might include the following: that necessary approvals of the plan were obtained; that the mechanisms for the approval of the plan were properly conducted; that these creditors receive a dividend under the plan which equates to what they would have received in liquidation proceedings; that the plan does not attempt to include provisions that are contrary to insolvency or other laws; that administrative claims and expenses are settled in full except to the extent that agreement has been reached with the holder of such claim or where there is agreement that certain expenses are subjected to different treatment; and that the claims of dissenting creditors are ranked in terms of the relevant insolvency laws of that jurisdiction. The court might be required to consider whether certain of these conditions have been satisfied before ruling that creditors are bound by the plan. ${ }^{4}$

The court may further have to order that secured creditors are bound by the plan; provided certain conditions have been satisfied. These conditions may include; that were the secured creditor not bound by the plan, enforcement of the security interest by the secured creditor would have a material adverse effect on achieving the purposes of the plan; that the interests of the secured creditor will be protected under the plan; and

1 UNCITRAL Legislative Guide on Insolvency Law Part 2 (2005) 226. Also see Burdette Legislative Framework for the Facilitation of Turnarounds in South Africa, Turnaround Management and Corporate Renewal, A South African Perspective (2011) 136.

2 Westbrook, Booth, Paulus \& Rajak A Global View of Business Insolvency Systems (2010) 156.

3 UNCITRAL supra $\mathrm{n} 1$ at 218.

4 Idem at 226. 
that the position of the secured creditor will not be prejudiced by the implementation of the plan. ${ }^{5}$

The forced acceptance of these dissenting creditors is necessary so as to ensure the chances of success of the reorganisation of the company. To the extent that these mechanisms result in an impairment to the claims of dissenting creditors without their consent, there is always the risk that creditors would be wary to provide credit in the future. ${ }^{6}$ Any interference with the sanctity of contract (contractual provision of credit by a financial institution) will always carry the risk of prejudice and impairment to the rights of those creditors who are forced to comply with the will of the majority. The risk of advancing credit and the possibility of corporate failure, coupled with the ability to rescue a failing entity, provides the necessary tension between allowing a company to lapse into liquidation (bankruptcy) or being rehabilitated through a rescue process.

The purpose of this article is thus to consider the binding offer provisions in the 2008 Companies Act that can result in dissenting creditors being forced to sell their voting interest to parties that support the rescue plan in order to allow for such plan to be adopted.

It is submitted that the rationale behind the binding offer procedure supports not only a goal of promoting debtor-creditor agreement but also the goal of achieving a reorganisation of a debtor company that might be facing a liquidation. The binding offer mechanism allows for a situation where goals diverge. Creditors who do not support the debtor company in its reorganisation objective, or at least not on the terms proposed, need to be forced to exit the process so that a reorganisation plan can be approved. ${ }^{7}$

It is further submitted that the ability to force a plan on dissenting creditors is a fundamental international principle required in a restructuring. ${ }^{8}$ Without it, dissenting creditors could hold out (wanting a bigger pay-out) and could ultimately cause the restructuring plan to fail and the company placed into liquidation. The ability to force dissenting creditors to sell their voting interests to those parties that wish to support the proposed plan averts the danger of having obstructive (hold-out) creditors wanting more out of compromise than that which would be acceptable to most other creditors, and thus holding willing creditors to ransom in a situation where liquidation of the company is inevitable.

Ibid.

Idem at 218.

Herbert Understanding Bankruptcy (1995) 342.

8 UNCITRAL supra $\mathrm{n} 1$ at 218. 


\section{The South African Binding Offer Mechanism - Section 153(1)(b)(ii) of the 2008 Companies Act}

\section{Section 153(1)}

Section 153 makes provision for various steps that are available to the business rescue practitioner or affected persons, in circumstances where the proposed business rescue plan has been rejected (failure to adopt) under section 152. From a reading of section 153, it appears that the intention of the binding offer mechanism is to ensure that a plan is 'forced' upon dissenting creditors.

The content that is required for a South African rescue plan to be formulated is set out in section 150, and the voting requirements for the plan's approval are set out in section 152(2)(a) and (b) of the 2008 Companies Act. The South African legislature allowed the business rescue practitioner considerable leeway in what is required to be set out in the plan. As long as the plan contains all of the information reasonably required to facilitate affected persons in deciding whether or not to accept or reject the plan, that would be sufficient. ${ }^{9}$

In terms of section 153(1)(a) of the Companies Act 71 of 2008 ('2008 Companies Act'), if a business rescue plan has been rejected (in terms of section 152(3)(a) or (c)(ii)(bb)), the practitioner may -

i) seek a vote of approval from the holders of voting interests to prepare and publish a revised plan; or

ii) advise the meeting that the company will apply to a court to set aside the result of the vote by the holders of voting interests or shareholders, as the case may be, on the grounds that it was inappropriate. ${ }^{10}$

Section 153(1)(b) states the following:

If the practitioner does not take any action contemplated in paragraph (a) -

(i) any affected person present at the meeting may -

(aa) call for a vote of approval from the holders of voting interests requiring the practitioner to prepare and publish a revised plan; or

(bb) apply to the Court to set aside the result of the vote by the holders of voting interests or shareholders, as the case may be, on the grounds that it was inappropriate; or

(ii) any affected person, or combination of affected persons, may make a binding offer to purchase the voting interests of one or more persons who opposed adoption of the business rescue plan, at a value independently and expertly determined, on the request of the practitioner, to be a fair and reasonable estimate of the return to that person, or those persons, if the company were to be liquidated.

9 S 150(2).

10 The grounds for setting aside a vote as being inappropriate are set out in s 153(7)(a)-(c). The ability for a company (through its business rescue 
Thus, in the event that a business rescue plan has been rejected, the practitioner may seek a vote of approval from the holders of voting interests to prepare and publish a revised plan. The opportunity to propose a revised plan is given to every affected person (including shareholders). ${ }^{11}$

In the event that a revised plan is not put forward in terms of section 153(1)(a), affected persons are entitled to consider making a binding offer to purchase the voting interest of dissenting creditors in order to 'force' the plan through. ${ }^{12}$

\section{The 'Binding Offer' Mechanism in Terms of Section 153(1)(b)(ii)}

The 'binding offer' principle is a concept quite new to South African law. Any affected person or combination of affected persons may make an offer to dissenting persons to buy the voting interests at liquidation value (such liquidation value to be appraised by an independent expert). In South African law one would, in the ordinary course, enter into an agreement of sale of something like a 'voting interest' which would require an 'offer' open to 'acceptance' by the offeree. ${ }^{13}$ From a literal

10 practitioner) to apply to court to set aside the result of the vote on the grounds that such votes were inappropriate, is a further mechanism (in addition to the $\mathrm{s}$ 153(1)(b)(ii) binding offer process) available to the business rescue practitioner to ensure that a plan is ultimately approved and implemented. In this regard see the findings in Ex Parte Target Shelf 284 CC; Commissioner, South African Revenue Service and Another v Cawood NO and Others $(21955 / 14 ; 34775 / 14)$ [2015] ZAGPPHC 740 (13 October 2015)and Shoprite Checkers (Pty) Ltd v Berryplum Retailers CC and Others 47327/2014 [2015] ZAGPPHC 255 (11 March 2015). Also see comments by Meskin, Kunst, Galgut, Delport, Vorster \& Burdette in Henochsberg on the Companies Act 71 of 2008 (2011 + ) ('Henochsberg') 530 on the meaning of the term 'inappropriate'. It is submitted that this mechanism will be used as an alternative to the 'binding offer' mechanism due to the uncertainty created by the various cases on s 153(1)(b)(ii), dealt with below. The purpose of s 153(1)(a)(ii) would also be to set aside a vote (in terms of $\mathrm{s}$ $153(2)$ ) and force the business rescue practitioner to either propose a new plan (in terms of s 153(1)(a)(i)) or be faced with having to file a notice of termination of the business rescue proceedings (s 153(5)). In the latter event, there is a strong possibility that the company will be placed into liquidation. Also see FirstRand Bank Ltd $v$ KJ Foods CC (in business rescue) (734/2015 [2015] ZASCA 50 (26 April 2017) and the manner in which the SCA dealt with the setting aside of a vote on the grounds that it was inappropriate in terms of s 153(1)(a)(ii) as read with s 153(7). Also see Swanepoel \& Gopal An inappropriate business rescue mess (Without Prejudice, July 2013) $16-17$.

11 See s 146(e)(i) and see Loubser The Business Rescue Proceedings in the Companies Act of 2008: concerns and questions (Part 2) 2010 TSAR 696. ('Loubser Concerns and Questions'). See ss 144(3)(g)(i) and 153(1)(b)(i)(bb).

12 S 153(1)(b)(ii).

13 See Van Rensburg, Lotz \& Van Rhijn in Joubert \& Faris (eds) The Law of South Africa 2nd ed Volume 5 Part 1 (2010), par 375: An 'offer' is defined as 'a statement of intention in which the offeror sets out to the person to whom the offer is made what performance and what terms he or she is 
reading of section 153(1)(b)(ii), it is submitted that it appears that an offeree can force a dissenting person to sell a voting interest at liquidation value. ${ }^{14}$

Of course, the aim and purpose of this section is to ensure that those affected persons who wish to vote in favour of a plan that has not been approved, be given the opportunity to buy out voting interests in order to get to the required threshold of 75 percent as set out in section 152(2) and in order to approve the business rescue plan. This averts deadlock and forces those dissenting creditors to sell out at negligible value as, by voting down the plan, these creditors have represented to all stakeholders that the plan (and the dividend offered therein) does not appear to be achievable and therefore not acceptable. Consequently, such creditors should, as a result, be happy to accept a lower or negligible dividend set at liquidation value. ${ }^{15}$

All creditors that oppose the adoption of the plan by voting it down are therefore at risk. If they dissent on the vote, they must realise that there is a possibility that they can be bought out at liquidation value. ${ }^{16}$ Liquidation value refers to a payment for a voting interest that has been independently and expertly determined to be a fair and reasonable estimate of what the holder of the voting interests would receive if the company were to be liquidated. This task is given to the practitioner who

prepared to bind himself or herself to'. An 'acceptance' of an offer is defined as 'a statement of intention in which the offeree signifies assent to the proposal embodied in the offer'. On a strict interpretation of s 153(1)(b)(ii), it does not appear that the offeror, once it submits a binding offer, allows the offeree any opportunity to accept or assent to the offer made to be bought out at liquidation value. The principle of offer and acceptance, it is submitted, is watered down by the inclusion of the 'binding offer' principle. The legislature appears to forego this principle in favour of ensuring that plans are 'pushed' through and voted upon at the $75 \%$ threshold set out in s 152(2); the objective being to save the distressed company, seemingly at all costs.

14 The author is strongly of the view that the effect of the binding offer procedure is in line with the South African business rescue objectives i.e. to ensure that a viable and workable plan is not rejected by 'hold-out' creditors, who refuse to accept the proposed dividend distribution proposed by a plan. Such creditors should be 'forced' to sell to those creditors who wish to support such a plan, and to do so at liquidation value. See discussion in par 1 above.

15 The concept of allowing those creditors who wish to approve the plan being able to buy up voting interests to reach the required voting thresholds set out in s 152 and to do so through the binding offer mechanism is unique. The previous s 311 compromise provisions set out in the Companies Act 61 of 1973 ('the 1973 Companies Act') allowed for the majority of creditors to bind the minority if a majority in number and two-thirds in value supported the s 311 scheme of management (subject to the sanction of the court - see s 311 (2) of the 1973 Companies Act). However, it is submitted, that the binding offer principles create a new dimension and opportunity to those creditors who wish to see the debtor company remain in business through an approved business rescue plan.

16 However, see how the SCA has watered down the principle in par 3 and 4 below. 
must appoint an independent expert to provide such determination. Such valuation is subject to review, reappraisal and re-evaluation by the court on application by the holder of the voting interest or the person acquiring it. ${ }^{17}$ This provision has been subject to some criticism by Loubser. She questions the basis upon which an offeror is not allowed to offer more than the liquidation value of the voting interest to make the offer more attractive to the offeree. The liquidation value of a concurrent creditor's claim, for example, would be closer to nil and a share in a company unable to pay its debts would definitely be worthless on liquidation. ${ }^{18}$

Loubser is of the view that this provision is one of the most disturbing provisions regulating business rescue proceedings. As a result of the lack of any explanation or clarification of this provision, it could possibly enable the expropriation without any compensation of a concurrent creditor's claim or a shareholder's shares. ${ }^{19}$

The word 'binding' has perplexed readers of the legislation. Initially the view was that 'binding' in section 153(1)(b)(ii) refers to an offer which, once made, cannot be retracted or changed. Do the words 'binding offer' mean that the offer is not necessarily binding on the offeror, but in fact also bound the offeree to the offer? The right of the offeree to apply to court for a review of the liquidation valuation made would support this interpretation, otherwise the offeree could simply refuse the offer. ${ }^{20}$

It is submitted that the 'binding offer' principle is an attempt to ensure that a plan is ultimately approved and implemented by the practitioner. It forces 'dissenters' to be forced to accept the terms of the proposed plan, or be bought out at liquidation value.

We now consider the various cases that have dealt with the binding offer principles envisaged by section 153(1)(b)(ii).

\section{African Bank Corporation of Botswana Ltd v Kariba Furniture Manufacturers (Pty) Ltd 2013 (6) All SA 471 (GNP)}

The issue was first dealt with in the matter of African Bank Corporation of Botswana Ltd $v$ Kariba Furniture Manufacturers (Pty) Ltd ('Kariba

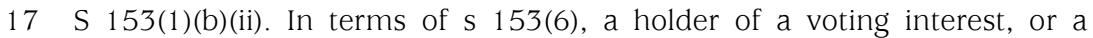
person acquiring that interest in terms of a binding offer, may apply to court to review, reappraise and revalue a determination by the independent experts in terms of s 153(1)(b)(ii).

18 Loubser Concerns and Questions supra n 11 697. Also see Loubser 'Some Comparative Aspects of Corporate Rescue in South African Law' (LLD dissertation 2010 UNISA) 138 ('Loubser LLD Thesis').

19 Loubser Concerns and Questions supra n 11 697-8.

20 Loubser LLD Thesis supra $n 18$ 138. Loubser states that an explanatory memorandum on this aspect of the legislation would have been of invaluable assistance here. 
(GNP)'). ${ }^{21}$ Judge Kathree-Setiloane considered the effect of section 153(1)(b)(ii) of the 2008 Companies Act. In this case, the bank voted against a proposed plan and the shareholders advised the practitioner that as a result, they wished to invoke the provisions of Section 153(1)(b)(ii) and make a binding offer for the bank's voting interest. The practitioner called a short adjournment of the meeting to consider the effect of the binding offer. The practitioner took the view that the offer was immediately and ipso facto binding on the bank and treated the offer as having been accepted by the bank. The practitioner duly amended the voting interest of the bank as holding zero percent and the shareholders as holding 95 percent of the voting interest of creditors. The plan was then approved on this basis. The judge confirmed that the concept of a 'binding offer' was novel to South African company law and was a 'last gasp' attempt to have a business rescue plan approved. ${ }^{22}$ The difficulty of interpretation resulted from the fact that no definition had been provided for the term 'binding offer'. Was it an offer binding on the offeror only (in the nature of an option) and as a result the offeree was free to accept it or reject it? Alternatively, was it binding on both the offeror and the offeree, such that the offeree is deemed to have accepted the offer once made? ${ }^{23}$

Judge Kathree-Setiloane was of the view that a 'cram down' process was indispensable to the successful implementation of a business rescue plan. Since 'cram down' is a 'process by which creditors are forced to accept a re-organisation or a business rescue plan, even against their wishes', it has the incidental effect of discouraging creditors from resisting or holding out for better treatment and it enables a business recue or re-organisation to proceed despite the objections of one or more disgruntled creditors. 24

The judge was of the view that the word 'binding' as it appears before the word 'offer' characterises the nature of the offer which the legislature envisaged under section 153(1)(b)(ii). Once the offer is made, it creates a vinculum juris or legal obligation on the part of the offeror and may not be withdrawn. The 'binding offer' is not an 'option' or 'agreement' in the contractual sense of the term, but rather a statutory set of rights and

212013 (6) All SA 471 (GNP) ('Kariba (GNP)'). See the decision reversed on appeal to the SCA below, n 84. Also see Wesso 'Business Rescue: The Position of Secured Creditors' (2014) De Rebus 35-36; Meskin Insolvency Law and its operation in winding up (1990) par 18.17.4.

22 Kariba (GNP) supra $\mathrm{n} 21$ at par 19.

23 Idem at par 22.

24 Idem at par 28. The judge refers to the US-styled 'cram down' procedure in the context of the South African 'binding offer' principles. Judge KathreeSetiloane distinguished between the two mechanisms and pointed out that the US cram down procedure is court-driven (unlike the binding offer mechanism in South Africa). The judge confirmed that where creditors refuse to assist, the US Bankruptcy Code provides for the court to confirm the repayment plan despite creditors' objections, provided that the requirements of s 1129 (b) of the US Bankruptcy Code are met, essentially allowing for the 'cramming down' on dissenting creditors. 
obligations from which neither party may resile. The court held that the binding offer will be binding on both the offeror and the offeree once made, predominantly to ensure compliance with the procedure to revive a business rescue and enforce the business rescue plan within the framework of section 153(4) of the 2008 Companies Act. ${ }^{25}$

Judge Kathree-Setiloane was of the view that once the binding offer is made, it is dependent upon either of the parties' acceptance of the value independently and expertly determined or by way of an order of the court as to the value of the offer, which will only become payable after such determination. ${ }^{26}$ Significantly, the practitioner would in any event not be able to proceed with the implementation of the adopted business rescue plan prior to finalising the payment of the binding offer. ${ }^{27}$

The reasoning is criticised by Henochsberg, ${ }^{28}$ where the author states that the court was incorrect in concluding that the 'offer' is 'binding' because, once it is made, it creates a vinculum juris or legal obligation on the part of the offeror which may not be withdrawn.

Henochsberg goes on to state that the 'compulsory' legal obligation established in terms of the judgment might very well have the effect that property (voting interests) would be expropriated contrary to section 25(1) of the Constitution of the Republic of South Africa, 1996. ${ }^{29}$

Notwithstanding, Judge Kathree-Setiloane found that the ability of an offeror to divest the offeree of its 'voting interest' at liquidation value served a compelling and legitimate purpose (in terms of section $7(\mathrm{k})$ of the 2008 Companies Act) and that the deprivation of such voting interest was in any event accompanied by compensation, expertly and independently determined and thus could not be seen as an 'arbitrary' deprivation of rights. ${ }^{30}$

It is submitted (see further discussion below) that Judge KathreeSetiloane's interpretation of the 'binding offer' principle is aligned with the intention of the legislature when it drafted section 153(1)(b)(ii). The offeror must be placed in a position where it can, with certainty, put forward a 'binding offer' to buy the dissenting creditor's voting interest at liquidation value (fairly determined), and the offeree must be forced to sell at such price. This creates certainty and allows those creditors who wish to support the proposed plan with the opportunity to acquire

25 Idem at par 29. See comments by Henochsberg supra $\mathrm{n} 10$ at 532.

26 Kariba (GNP) supra n 21 at par 36. The judge went on to further consider the determination of the value of the voting interest (idem at par 30-31) and the constitutional challenge raised by the bank to its rights to property, access to court and equality (idem at par 37-55). See Blom \& Ledwaba 'A Binding Offer' Without Prejudice November 2013 40-1.

27 See Kariba (GNP) supra n 21 at par 33.

28 See comments by Henochsberg supra $\mathrm{n} 10$ at 532.

29 Ibid.

30 Kariba (GNP) supra n 21 at par 46. 
sufficient voting interests to get to the voting thresholds set out in section 152(2) of Chapter 6.

\section{DH Brothers Industries (Pty) Ltd v Gribnitz NO and Others 2014 (1) SA 103 (KZP) ('DH Brothers')}

A contrary view was provided in the case of DH Brothers Industries (Pty) Ltd and Karl Johannes Gribnitz NO and Others ('DH Brothers'). ${ }^{31}$ Judge Gorven disagreed with the findings in the Kariba (GNP) case supra and stated that a 'binding offer' itself could not, on its own, constitute a 'set of statutory rights and obligations'. The legislature did not intend to create a specific deeming provision of acceptance on the part of the offeree or have stated that the offer, once made, gave rise to binding obligations between the parties. Instead, the legislature used the word 'offer' which can only emanate from one party. Section 153(1)(b)(ii) appears to be consistent with this approach. In order to give rise to legal obligations on the part of both parties, an offer requires acceptance. The intention is to conclude a legal transaction of purchase and sale, a wellestablished legal concept. The word 'binding' qualifies the word 'offer' and nothing else. It specifically does not refer to the opposing creditor, as the offeree. If the legislature had intended this, then the provision would have said that the affected person could make an offer which is 'binding' on the opposing creditor. The court held that the words 'binding offer' can only mean that the offeror may not retract the offer until it is accepted or rejected. ${ }^{32}$

The court confirmed that an offer under section 153(1)(b)(ii) necessitated an adjournment of the section 152 meeting. As time is of the essence in a business rescue proceeding, an offeror should not be able to make an offer which has the effect of extending the moratorium without being obliged to keep open the offer until acceptance or rejection. Delays could result in a series of offers being made, withdrawn prior to the date of each adjourned meeting, with the intention of keeping the business rescue proceedings alive indefinitely. A new binding offer, in effect, could be made at each consecutive adjourned meeting which does not garner the requisite support for the plan. Further, the outside expert required to fix the price of the voting interest would incur wasted expenditure each time the offer is withdrawn. ${ }^{33}$

Judge Gorven was critical of the Kariba (GNP) decision supra and, in particular, where a court makes words such as 'binding offer' mean what such court thinks they should mean. The court referred to National Credit Regulator $v$ Opperman, ${ }^{34}$ and warned that courts should resist the

312014 (1) SA 103 (KZP) ('DH Brothers').

32 On the nature and meaning of an 'offer' see Joubert General Principles of the Law of Contract (1987) 37. Also see on the rules of offer and acceptance Kahn, Lewis \& Visser Contract and Mercantile Law: Second Edition (Volume 1) (1988) 55.

33 Idem at par 43-44

342013 (2) SA (1) (CC) 
temptation to substitute what they regard as 'reasonable, sensible or business-like' for the words used. To do so is to cross the divide between interpretation and legislation. ${ }^{35}$

Judge Gorven went on to state that the Kariba (GNP) interpretation of 'binding offer' runs counter to the provisions of section 145(2)(a) the 2008 Companies Act. Section 145(2)(a) provides that each creditor has 'the right to vote to amend, approve or reject a proposed business rescue plan, in the manner contemplated in section 152'. The loss of a voting interest is expropriation. Such compulsory loss would have to be made clear if it were contemplated by the legislature. The legislature chose to confer this unqualified right in the very context of voting for or against the adoption of a plan. If such a clearly formulated right were to be qualified or taken away, it would have done so in equally clear terms. ${ }^{36}$

The judge was of the view that in any event, the provisions of section 152 apply afresh at the adjourned meeting. On the Kariba (GNP) approach, section 145(2)(a) or section 153(4)(b) or both would need to be suitably qualified so as to exclude a vote at the adjourned meeting by a creditor to whom a binding offer has been made. This was not done. Consequently, an opposing creditor to whom a binding offer has been made remains entitled in terms of section 145(2)(a) to vote. The necessary implication is that where a right is not qualified or taken away, an opposing creditor cannot be deprived of the right to vote against his or her will. The necessary corollary is that the offer cannot give rise to obligations on the part of the opposing creditor which would result in the compulsory loss of its voting interests. Judge Gorven was further of the view that the binding offer must thus be construed as an offer which can be accepted or rejected by the opposing creditor. ${ }^{37}$

The court held that the Kariba (GNP) interpretation of a 'binding offer' was incorrect. If a plan is rejected at a meeting, both the practitioner and affected persons are provided mechanisms to attempt to keep the plan alive. ${ }^{38}$ A court can be approached to set aside the vote on the basis that it is inappropriate or further seek a vote to amend the plan. ${ }^{39}$ In contrast, opposing creditors (who voted against the plan) are not given the right to approach the court to set aside an approving vote or the acquisition of their voting interests. It seems highly unlikely that the legislature would deprive them of their right to vote without their acquiescence, without at least giving them the right to challenge the adoption of a plan secured as a result of their deprivation. ${ }^{40}$

Further, section 145(2)(b) provides a creditor a right to present an offer to acquire the interests of any or all of the other creditors in the

DH Brothers supra $\mathrm{n} 31$ at par 60.

Idem at par 46.

Idem at par 47.

S 153(1)(a) and (b).

See $\mathrm{n} 10$ for meaning of 'inappropriate vote'.

Idem at par 48. 
manner contemplated in section 153 if a business rescue plan is rejected. The same right is accorded to trade unions and employees in section $144(3)(g)(i i)$ and to holders of the company's securities in section 146(e)(ii).

The court referred to section 153(6) which states:

A holder of a voting interest, or a person acquiring that interest in terms of a binding offer, may apply to a court to review, re-appraise and re-value a determination by an independent expert in terms of subsection (1)(b)(ii).

In terms of the Kariba (GNP) approach, the value of the voting interests is determined only after the adoption of a plan. At that stage, the offeree is no longer 'the holder of a voting interest'. Judge Gorven was of the view that the transfer of the voting interest can only pass after the value has been finally determined, at the very earliest. Judge Gorven determined that voting interests can only pass upon payment of the purchase price as is the case at common law where there is no stipulation to the contrary. 41

The court deliberated further over how far the South African process would go in order to force a plan on dissenting creditors. As stated in the Kariba (GNP) case, ${ }^{42}$ the purpose of Section 153(1)(b)(ii) is 'to enforce a revised business rescue plan'. However, Judge Gorven was quick to point out that the purposes of business rescue, as set out in Section 7(k) of the 2008 Companies Act, does not support an interpretation leading to a forced acceptance of business rescue plans at all costs. If that were so, the 75 percent majority vote would not have been stipulated. ${ }^{43}$

The court further criticised Kariba as saying that 'the offeree is therefore adequately protected since it cannot receive less than it would receive if the company were to be liquidated'. ${ }^{44}$ Section 153(1)(b)(ii) requires that the purchase price must be independently and expertly valued based on a 'fair and reasonable estimate of the return to that person .... if the company were to be liquidated'. Judge Gorven pointed out that this determination could only be an estimate and could never be a calculation of a definitive amount, for the simple reason that this could only be possible in a finalised liquidation and distribution account after liquidation. Further, there are many factors which will influence a liquidation value and it would be very difficult to accurately establish such liquidation value with any degree of accuracy. Issues such as impeachable dispositions, value of claims against directors, estimates on values of the assets and collection of amounts due by way of litigation

41 Idem at par 52. The court referred to Ghandi SMP Properties (Pty) Ltd 1983 (1) SA 1154, at $1157 \mathrm{G}-\mathrm{H}$. Broom J said 'in the absence of some clear stipulation to the contrary, payment and transfer takes place pari passu ....

42 Kariba (GNP) supra $n 21$.

43 Idem at par 54

44 Kariba (GNP) supra n 21 at par 32. 
would all affect the ability of an expert to arrive at an accurate determination. 45

All of these inaccuracies impact on the ability of the opposing creditor's willingness to accept the offer. It is cold comfort to say that a creditor may approach the court to review, reappraise and revalue the determination. ${ }^{46}$ The court is unlikely to be in any better position to make such determination. In any event, the opposing creditor might reasonably take the view that insolvency is a preferable option to adoption of the plan. If the practitioner or any affected person believes that this view is unreasonable and the opposing creditor votes against the plan resulting in the plan being rejected, they have recourse to the court to set aside the vote on the basis that it was inappropriate. ${ }^{47}$

Whether or not the court has the power to impose the plan on dissenting creditors was also considered. Section 153(7) does not accord to the court the power to make an 'appropriate order'. The court is limited to setting aside the rejecting vote. The 2008 Companies Act is silent thereafter. Section 152(4) makes a plan binding on the company, all creditors and all holders of the company's securities, whether or not they were present at the meeting which adopted the plan or voted for it. 48

Judge Gorven concluded by confirming that in his view, the "binding offer' is an offer which cannot be withdrawn by the offeror and is open to acceptance or rejection by the opposing creditors to whom it is made. If accepted, it gives rise to an agreement of purchase and sale. It is a sale for cash because "[i]n the absence of an express term as to the sale being for cash or on credit there is a presumption that it is for cash'. The judge was of the view that the acceptance or rejection need only take place once the value has been finally determined. The independent expert is only obliged to reach a determination by the date of the adjourned meeting, whereafter the voting interests are transferred on payment of the determined sum. Once this has taken place, the voting interests are settled and the vote on the plan can take place. If adopted, the plan can and must be implemented by the practitioner. Once it has been substantially implemented, the practitioner must file a notice to that effect and the business rescue proceedings come to an end. If it is not approved, it is rejected and, if s153 is not invoked the business rescue proceedings come to an end. ${ }^{49}$

\footnotetext{
45 DH Brothers supra $n 31$ at par 55.

46 S 153(6).

47 S 153(1)(a)(ii). DH Brothers supra $n 31$ at par 56.

48 Idem at par 58.

49 Idem at par 69. For a comparison between the two judgments, see Marquand Who does a 'binding offer' bind? Without Prejudice August 2014 12-13. Also see Wesso n 43 35-6; Gootkin 'The problem of compelling shareholders to approve business rescue plans' Without Prejudice May 2014 $12-13$.
} 
If the decision in $D H$ Brothers ${ }^{50}$ is correct, then the position of the secured creditor, whether large or small in respect of voting interest, is protected, since it cannot be deprived of its secured right simply by means of a 'binding offer'. A secured creditor will have to accede to the discharge of the order for it to be valid. This interpretation of section 153(1)(b)(ii) accords more readily with the law relating to offer and acceptance than does the interpretation in the Kariba (GNP) ${ }^{51}$ matter. If the legislature intended for the provision to veer so significantly from the existing law, as suggested in the Kariba (GNP) case, it would have done so more clearly. ${ }^{52}$

\section{Absa Bank Limited v Caine NO and Another; In Re Absa Bank Limited v Caine and Another 3813/2013, 3914 (2013) [2014] ZAF SHC ('Absa Bank case')}

In Absa Bank Limited v Caine NO and Another 53 ('Absa Bank case'), Judge Daffue held that a 'binding offer' should be regarded as an offer binding on the offeror and not the offeree, who should have the discretion to either accept or reject the offer.

In the Absa Bank case, the judge advised that it was apparent that there was uncertainty and therefore the legislature was urged to consider the issue afresh and make necessary amendments. ${ }^{54}$

\section{African Banking Corporation of Botswana Ltd v Kariba Furniture Manufacturers (Pty) Ltd and Others 2013 (228/2014) [2015] ZASCA 69 (20 May 2015) ('Kariba (SCA)')}

The debate about what is meant by a 'binding offer' in terms of section 153(1)(b)(ii) of the 2008 Companies Act appears to have been finally determined. In an appeal to the Supreme Court of Appeal (SCA), the judgment of the court a quo in Kariba (GNP) supra was set aside in the Kariba (SCA) matter. ${ }^{55}$ On appeal, it was contended that a binding offer made in terms of section 153(1)(b)(ii) did not automatically bind the

50 DH Brothers supra $\mathrm{n} 31$.

51 Kariba (GNP) supra n 21

52 Wesso supra $\mathrm{n} 43$ at 36 . Henochsberg extensively criticised the finding in the Kariba (GNP) case at n 10 530-531. The authors of Henochsberg prefer the interpretation of a 'binding offer' in the DH Brothers case at 533. Also see comments on Kariba (GNP) and DH Brothers in Locke \& Esser Company Law and Stock Exchanges: Annual Survey of South African Law (2013) 279286.

53 Absa Bank Limited v Caine NO and Another; In Re Absa Bank Limited v Caine NO and Another 3813/2013, 3914 (2013) [2014] ZAF SHC ('Absa Bank case').

54 Absa Bank case supra n 53 at par 37.

$552013(228 / 2014)$ [2015] ZASCA 69 (20 May 2015) ('Kariba (SCA)'). The judgment provides a good synopsis of the previous cases as well as the manner in which the court came to its finding on the meaning of a binding offer. 
offeree. Instead, the use of the term 'binding offer' in the section is intended to convey that the offer, once made, could not be withdrawn by the offeror. 56

The judgment (handed down by Acting Judge Dambuza) referred to the position in the US, and how 'impaired' classes of creditors are to be treated. ${ }^{57}$ The SCA were very careful in distinguishing the differences in approach in the cram down procedures available in a Chapter 11 procedure under the US Bankruptcy Code when compared to the South African 'binding offer' mechanism. The court found that the court a quo had erred in placing too heavy reliance on the US cram down approach when interpreting the section 153(1)(b)(ii) procedure. The court made reference to the manner in which dissenting creditors are dealt with by the US Bankruptcy Court. The US Bankruptcy Court would determine whether the rejection of a business plan by creditors should be ignored. Section 1129(a) of the US Bankruptcy Code (referred to above) sets out specific peremptory requirements that must be satisfied before a court can confirm a rescue plan. ${ }^{58}$

The court stated that a distinguishing factor is that the making of the offer in the business rescue procedure is a step 'separate and antecedent' to the second round of voting on the adoption of the rescue plan. Therefore, the meaning of 'binding offer' falls to be considered on its own merits and separately from the merits of a rescue plan. ${ }^{59}$

The court stated:

The term 'binding offer' must be appreciated against the meaning of 'offer' as hitherto understood in this country. In everyday use, the word 'offer' signifies a presentation or a proposal to someone for acceptance or rejection; it is 'an expression of readiness to do or give something; [or] an amount of money that someone is willing to pay for something, In South African parlance, an offer is an invitation to consent to the creation of obligations between two or more parties. 'What distinguishes a true offer from any other proposal or statement is the express or implied intention to be bound by the offeree's acceptance.' Therefore, the settled meaning, both in the general use and in the more technical legal use of the word 'offer' is that it is only on acceptance that an offer creates rights and obligations. ${ }^{60}$

Clearly, an ambiguous proposal cannot be classified as an offer, and the terms of the offer must cover the minimum requirements of the

56 See discussion in par 12-25 of the Kariba (SCA) judgment supra n 55.

57 Idem at par 16.

58 Ibid. The requirements set out in s 1129(a) of the US Bankruptcy Code, include that the plan must be proposed in 'good faith', each 'impaired' class of creditors must have either accepted the plan or each creditor must stand to receive no less than it would receive under liquidation, each class of creditors must accept the plan or be 'unimpaired' and there must be no likelihood of confirmation of the plan being followed by a 'liquidation' or further business 'reorganisation'.

59 Idem at par 17.

60 Idem at par 18. 
proposed contract. A mere regurgitation of the provisions of section $153(1)(d)$ (ii) cannot constitute a proper binding offer. The offeree (in this case the bank) was entitled to know who exactly was making the offer and what the details were thereof, including the price or determine value and where, when and how payment would be effected. ${ }^{61}$

Section 153(1)(b)(ii) presupposes that for the making of a binding offer, that the rescue plan will contain sufficient detail from which a determination of the value of the creditor's voting interest can be readily and reliably ascertained, such that a binding offer will embody the price or value at which the offer is made. Section 150(2) provides that the business rescue plan must contain all the information reasonably required to enable the affected persons to decide whether or not to accept or reject it. The content of what is required to be set out in the plan is set out in section 150(2). It is the same level of detail that is required to calculate a fair and reasonable value of the voting interests. ${ }^{62}$

The court held that not only must there be an offer, but it must be 'binding'. The significance of such a description can only be that once the offer is made it cannot be withdrawn by the offeror. ${ }^{63}$ The court rejected the Kariba (GNP) supra decision as such an outcome would be extraordinary, and the effect would be to deprive an offeree of an established right to accept or reject an offer. Had that been the intention, the legislature would not have used a word which connotes an expectation of a response. ${ }^{64}$ Consequently, the court found that a binding offer remains predominantly similar in nature to the common law offer, save that it may not be withdrawn by the offeror until the offeree responds thereto. 65

The court strongly disagreed with the court a quo's finding that once a binding offer is made to purchase a voting interest, the holder thereof is summarily divested of its voting interest, which includes a divestment of its interest without any determination of affordability on the part of the offeror. ${ }^{66}$ The court concluded that there is no language in section 153(1)(b)(ii) that should result in a situation where once a binding offer is made to purchase a voting interest, the holder thereof is summarily divested of its voting interest without allowing such holder to have the ability to determine the affordability of such offer on the part of the offeror. Section 153(6) states that a holder of a voting interest or a person acquiring that interest in terms of a binding offer, may apply to court to review, reappraise and revalue a determination by an independent expert in terms of section 153(1)(b)(ii). The legislature has therefore

61 Idem at par 19.

62 Idem at par 20.

63 Idem at par 21. In contrast to the ordinary meaning ascribed to an offer, that it becomes binding on acceptance and may be withdrawn before then.

$64 \mathrm{Ibid}$. Reference was made to Judge Gorven's comments in DH Brothers supra $\mathrm{n} 31$ at par $40-41$.

65 Kariba (SCA) n 55 at par 21.

66 Idem at par 22. 
made express provision for two categories of persons: those who are holders of voting interests and those in the process of acquiring a voting interest. The court was of the view that this suggests that although a binding offer may have been made (during consideration of the business rescue plan), finalisation of the aspects relating thereto, including transfer of the voting interest, is not necessarily immediate. This is consistent with the established meaning of an offer. The court found that the court a quo's interpretation would immediately divest interested holders of their interest once the binding offer is made. This would be untenable. The court ruled that any other interpretation cannot lead to a sensible, business-like result and therefore cannot be supported. ${ }^{67}$

In summary, the SCA held that in order for there to be a binding offer, it had to be accepted by the offeree. Thus a binding offer made to a creditor who opposes a business rescue plan is not automatically binding on the offeree. The court held that in order for there to be a binding offer, it had to be accepted, and that an offer merely regurgitating the terms of the section without any mention of a purchase price, did not constitute an offer to purchase. The offer made to purchase the voting interest of the appellant bank was held not to be binding on the appellant and thus the relevant business rescue plan was set aside.

\section{The 'Watering Down' of the Binding Offer Mechanism}

The effect of the judgment of the Kariba (SCA ${ }^{68}$ decision may be viewed as watering down the ability to 'force' the plan on dissenting creditors and is (in the author's view) directly in conflict with the true intention of section 153(1)(b)(ii). It is submitted that as a result of the finding in Kariba (SCA), the offeree would be in a position to determine if the offer that is made to buy out its voting interest is acceptable or falls to be rejected. In practice, it is submitted, a negotiation will take place between the offeror and the offeree to determine a 'fair price' for such voting interest. However, if the offeree becomes difficult, the offeror will not be in a position to force the offeree to accept the offer, thus being unable to 'force' the plan on the dissenting creditor. ${ }^{69}$

67 Idem at par 24-25. Also see views of concurring judges of appeal in Kariba (SCA), par 41-56. The Kariba (SCA) judgment was followed in the unreported judgment of Gqwaru and Another v Magalela Architects CC and Another (19959/2016) [2017] JAGPJHC 32 (23 February 2017). Also see analysis by Gribnitz and Lowery To agree or not to agree Without Prejudice (August 2016) 10 - 11 and Cebisa in Business Law \& Tax Review, Business Day (8 November 2015).

68 Kariba (SCA) supra $n 55$.

69 The judgement goes further to confirm that any offer made must be capable of acceptance. Therefore the offer must (in the author's view correctly so) cover certain minimum requirements of the proposed contract, such as details of the person/entity who makes the offer, the price 
It is submitted that the SCA's ruling has made significant inroads into the binding offer principle. As stated by Judge Kathree-Setiloane in Kariba (GNP), the purpose of section 153(1)(b)(ii) is to provide a swift and efficient procedure to revive a business rescue procedure after the rejection of a business rescue plan. The offeree is in any event protected as, if the value of the voting interest is fairly determined by an independent expert, such offeree would in reality not receive anything less than it would have received in the event of the company ending up in a liquidation. ${ }^{70}$

Whether the process as envisaged by section 153(1)(d)(ii) was intended to be a consensual process, rather than a forced sale, remains unclear. ${ }^{71}$ If a consensual process was intended, there is the counterargument that it would appear to be unthinkable that a creditor, especially a concurrent creditor, would accept an offer for a claim in an amount that the creditor would in any case receive in a winding up. ${ }^{72}$

It is the author's view that there must be an 'end game'. A creditor who would be willing to support a rejection of a workable proposed plan (by voting against a plan), where clearly other creditors (supportive of the plan) would be willing to make the effort to 'buy up' such dissenting voting interests in order to ensure that the plan is voted through, must be 'forced' to sell at a 'liquidation value' price i.e. that which such creditor would be willing to accept if the company had to go into liquidation.

In order to prevent hold-out creditors from holding other supporting creditors to ransom, it is submitted that the Kariba (GNP) (judgment of Judge Kathree-Setiloane) ${ }^{73}$ approach should be favoured. That is, once a 'binding offer' is made in terms of section 153(1)(b)(ii), it will have the effect of binding both the offeror and the offeree. Once made, the opposing or dissenting creditor must be forced to sell its voting interest to the offeror on the terms proposed in the offer. Any dispute on the price (by either the offeror or the offeree) determined for such voting interest should be dealt with by the expert determination provided for in section 153(6).

or determined value, and where, when and how payment would be effected. See Kariba (SCA) n 55 at para 19-20. It is submitted that had the offer in the Kariba (SCA) case been made in clear and unambiguous terms, it might have affected the court's decision in this case. It is possible that a similar matter might again come before the SCA where the court is required to assess the effect of a clear, precise and unambiguous offer. This might result in a different outcome in respect of what is meant by the binding offer in s 153(1)(b)(ii).

70 See Kariba (GNP) supra n 21 at par 31-32.

71 Henochsberg supra $n 10$ at 534.

72 Ibid. However, see the obiter remark made by Judge Gorven in DH Brothers n 31 (par 55) where the judge was of the view that the determination is in any event on an 'estimate' and other factors such as impeachable transactions and possible litigation recoveries that might arise as a result of the liability of directors in terms of s 77 of the 2008 Companies Act might influence the size of the final dividend. 
It is further submitted that the only way practitioners, creditors, lawyers and our courts will reach a position where they can definitively determine the meaning of a 'binding offer' will be where the legislature formulates (by an amendment to section 128(1) of Chapter 6) an appropriate definition of the term 'binding offer' as set out in section 153(1)(b)(ii). It is suggested that a new definition be inserted to define a 'binding offer' to mean an offer put forward by an offeror for the voting interests of the offeree where, once submitted, is binding on both the offeror and the offeree in terms of such sale transaction. The ability for an independent person to review the 'value' remains in place and is a safeguard for 'unfair' or 'unreasonable' values of voting interests having been determined. Any other interpretation renders the binding offer provision set out in section 153(3)(1)(b)(ii) meaningless and disables viable plans from being approved as a result of the potentially unconscionable conduct of opposing, hold-out creditors. ${ }^{74}$

What of course is not of assistance is the 'shoddy drafting' of the legislation (section 153) which gives rise to considerable uncertainty. ${ }^{75}$ Amendments to the section (as proposed by Judge Leach in the concurring judgment in Kariba (SCA), ${ }^{76}$ include whether the offeree has a period of time in which to consider whether to accept or reject an offer; the effect of an offer being rejected; whether an offer can be conditional and which conditions would be permissible; whether an offer excludes the making of a counter-offer or any other offers being made by other affected persons and, if not, how offers are to be ranked. ${ }^{77}$ As stated by Loubser, ${ }^{78}$ "it was regrettable that the drafters of the provisions regulating the new rescue procedures did not exercise more care and that the unclear, confusing and sometimes alarming provisions regulating the business rescue proceedings ... will certainly not assist in making the procedure more acceptable or successful.'

\section{Conclusion}

The binding offer principle is a strong feature of restructuring mechanisms in international jurisdictions and the South African legislature, in the author's view, recognised this as an essential feature of the rescue legislation.

It is submitted that the binding offer principle ensures that viable plans are ultimately 'pushed through' by the provisions of section 153(1)(b)(ii). The requirement that dissenting creditors (even if in the majority) should be forced to sell their voting interests at liquidation value is aligned to the principles of rescue and as is set out in section $7(\mathrm{k})$ of the 2008

74 See Levenstein An appraisal of the new South African business rescue procedure LLD Thesis 2015 University of Pretoria 602.

75 Kariba (SCA) n 55 at par 43.

76 Ibid.

77 Ibid.

78 Loubser LLD Thesis n 18 700-701. 
Companies Act. ${ }^{79}$ If as a result of the rejection of the plan, the company is facing liquidation, the legislature remains supportive of the notion that the company should survive, jobs retained and the company continue to contribute to the South African economy.

International principles of rescue and restructuring support forcing dissenting creditors who voted against the plan, to be placed into a position where they are forced to sell at liquidation value to those creditors who wish to vote in favour of the proposed plan. ${ }^{80}$ According to the SCA's recent finding in Kariba (SCA), the offeree will now be in an enviable position whereby it can 'negotiate' the liquidation value and price at which such offeree will sell to the offeror.

It is clear that the 'binding offer' principle, together with the principle set out in section 154(1), ${ }^{81}$ creates the ability to ensure that a plan (and its terms) become binding on all creditors in business rescue. There must be a point reached where those creditors who disapprove of the plan and who would prefer the company to be placed into liquidation, ${ }^{82}$ be forced to give up their voting interest at liquidation value. If such creditor is willing to take the minimal liquidation value in respect of a pay-out on its claim, then such a creditor must be prepared to 'walk away', having had its voting interest purchased from it at the same or similar value. The legislature provides the opportunity to make the binding offer available to any affected persons (or a combination thereof). The term 'binding', in the author's view, must be interpreted as being 'binding' on both the

$79 \mathrm{~S} 7(\mathrm{k})$ states that one of the purposes of the 2008 Companies Act is to provide for the efficient rescue and recovery of financially distressed companies, in a manner that balances the rights and interests of all relevant stakeholders. It is submitted that the legislature intended that the debtor company, provided it is rescuable, should be the focus, and not necessarily the interests of those creditors who would prefer to support the liquidation of the company with the consequent job losses as a result. The legislature ensured that the Chapter 6 legislation provided employees and trade unions (as affected persons) to have a participative role in the business rescue process (see s 144) and provided employees who work for the debtor company after commencement of the business rescue) with a super-priority status as creditors in the ranking of creditors' claims in the rescue process (s 155). It certainly appears that the South African legislature wanted to ensure the survival of the debtor company to occur at all costs, thereby ensuring that job retention was a contributing factor to the success of the business rescue process in South Africa. Thus, the 'binding offer' mechanism was put in place to ensure that hold-out creditors could not prevent the achievement of these goals.

80 UNCITRAL $\mathrm{n} 1$ at 218 and 226.

81 S 154(1) ensures that once a plan has been approved by creditors, a creditor who has acceded to the discharge of the whole or part of a debt owing to that creditor will lose the right to enforce the relevant debt or part of it.

82 In terms of s 153(5), "if no person takes any action contemplated in ss (1), the practitioner must promptly file a notice of the termination of the business rescue proceedings'. The notice of termination would bring business rescue proceedings to an end, and which would result, in all likelihood, in the company's liquidation (either brought by the practitioner, a creditor or by the company itself). 
offeror as well as the offeree. To interpret such wording in any contrary manner, would not do justification to the obvious result that would be expected from the South African rescue process, namely the acceptance of a workable plan designed to rehabilitate ${ }^{83}$ the company and place it back into the South African economy.

'Hold-out' creditors (shareholders) are recognised internationally as parties who cannot be allowed to 'hold' other creditors (shareholders) to ransom and allow the company to collapse into liquidation. It is submitted that the 'binding offer' principle is aimed at preventing a 'scorched earth' philosophy of 'if I am going to go down then all must go down with me!'. Dissenting creditors (and shareholders) must be placed in a position where they are forced to sell their voting interest to the general body of creditors (shareholders) who support voting in favour of the plan and for the plan to be implemented.

The Kariba (SCA) judgment, unfortunately, does not assist with the imposition of this principle. Dissenting creditors are placed in a favourable position where they have the opportunity to 'negotiate' the terms of such 'buy-out'. The ability to submit a 'binding offer', as intended by the legislature, has thus been watered down and will result in challenges to the successful implementation of the binding offer principle in business rescue proceedings in the future. The 'mandatory' contractual argument, as envisaged by Kariba (GNP) would, in the author's view, clearly support the purpose of business rescue, namely ensuring that the company is rescued by the approval of a workable and viable plan. It is however conceded that the wording of the section does not necessarily make this position clear, and thus an amendment is necessary. ${ }^{84}$

It is submitted that the Kariba (SCA) judgment has provided dissenting creditors with the 'poison pill', designed to discourage a hostile takeover of a voting interest and has provided dissenting creditors with the opportunity to vote down the plan, with no further opportunity for an effective binding offer mechanism. It is further submitted that this could never have been the intention of the legislature in the formulation of section $153 .{ }^{85}$ Thus, it is highly recommended that when the provisions of Chapter 6 are considered for legislative amendment, the proposals set out above are seriously considered and implemented. As a result,

83 See s 128(1)(b) - "business rescue has the clear aim of rehabilitating the financially distressed company and ... which maximises the likelihood of the company continuing in existence in a solvent manner.'. (s 128(1)(b)(iii)). It is submitted that the binding offer mechanism clearly ensures that the rescue objectives are achieved.

84 See Henochsberg supra n 10 at 534.

85 In support of the author's view, on 16 March 2007, in a briefing on the status of the draft Companies Bill, clear reference was made to the ability of the creditors (and employees) to buy out any dissenting creditor. No mention is made of the need for negotiation on issues such as price and terms. See '16 March 2008 Draft Companies Bill: briefing by the Department of Trade \& Industry - Parliamentary Monitoring Group’ 4. 
certainty of the 'binding offer' mechanism will create a definitive and properly considered approach when dealing with hold-out creditors in a business rescue. 